\title{
Microbial Succession and the Dynamics of Chemical Compounds during the Solid-State Fermentation of Pu-erh Tea
}

\author{
Yan Ma ${ }^{1}$, Shuangmei Duan ${ }^{1}$, Donglian Zhang ${ }^{1}$, Xiaoqin Su ${ }^{1}$, Dongying Zhang ${ }^{1}$, Caiyou Lv ${ }^{1, *}$ \\ and Ming Zhao ${ }^{1,2, *}$ \\ 1 College of Longrun Pu-erh Tea, Yunnan Agricultural University, Kunming 650201, China; \\ mayan202@163.com (Y.M.); duanshuangmei11@163.com (S.D.); zhangd1912@163.com (D.Z.); \\ suxiaoqin0520@163.com (X.S.); zhangdongying365@163.com (D.Z.) \\ 2 State Key Laboratory for Conservation and Utilization of Bio-Resources in Yunnan, Kunming 650201, China \\ * Correspondence: caiyou.ok@163.com (C.L.); zhaoming02292002@aliyun.com (M.Z.); \\ Tel./Fax: +86-871-6522-6565 (C.L. \& M.Z.)
}

Academic Editor: Hidenori Otsuka

Received: 20 September 2016; Accepted: 17 January 2017; Published: 10 February 2017

\begin{abstract}
An in-depth knowledge of the microbiota and metabolites in the solid-state fermentation (SSF) of Post-fermented Pu-erh tea (Pu-erh Shucha, PFPT), a Chinese traditional tea with various health benefits, is essential to develop modern fermentation technology. In this work, the microbial diversity and succession in two laboratory-developed SSF protocols for PFPT were investigated using pyrosequencing analyses of the bacterial $16 S r R N A$ and fungal $18 S r R N A$ genes. The active bacteria in the initial stages of SSF (seven days) were from the raw materials and environment, with a dominance of Proteobacteria in both the raw materials and SSF after seven days. The environmental bacteria were inoculated into the tea mass throughout the fermentation process and multiplied, with a dominance of Firmicutes at day 14 and 21, and then Firmicutes and Actinobacteria at the last stages of fermentation (day 28 and 35). The dominant fungi came from the raw material and were identified at the genus level as Aspergillus throughout the SSF process. The contents of tea polyphenols, free amino acids, gallic acid, theaflavin, thearubigin, and catechins decreased significantly $(p<0.05)$, while the level of theabrownin increased significantly $(p<0.05)$. The caffeine content showed no significant change $(p>0.05)$. In total, 30 bacterial and three fungal genera showed significant correlations to $1-8$ and 3-4 identified tea compounds, respectively $(p<0.05)$. The dynamics of the microbiota and chemical compounds, and correlations between their changes in the SSF of PFPT were revealed, and present a foundation for further studies on the microbial effects on chemical compounds.
\end{abstract}

Keywords: post-fermented Pu-erh tea; microbiota; solid-state fermentation; microbial community

\section{Introduction}

Post-fermented Pu-erh tea (Pu-erh Shucha, PFPT) is a well-known traditional Chinese tea with special sensory characteristics including mellow taste, stable flavor, and brownish-red color [1]. Additional, in vivo, in vitro, and clinical studies have suggested that PFPT has multiple health benefits, such as hypolipidemic, antiobesity, antimutagenic, antioxidative, antitumor, free radical scavenging, and toxicity-suppressing activity [2]. As a healthy beverage, it is popular in Southeast Asia and has also been introduced to the Western marketplace in recent years.

Unlike the raw material of black tea, fresh tea leaves [3,4], the raw materials of PFPT are sun-dried green tea (a variety of green tea products) produced from Camellia sinensis var. assamica (JW Masters) Kitamura [5]. In PFPT manufacturing, the post-fermentation process is crucial. In this process, the 
sun-dried tea leaves are stacked for a few weeks, leading to a series of oxidation, condensation, and degradation reactions in the chemical constituents of the tea [6]. From the microbiological view, the post-fermentation of PFPT is a solid-state fermentation (SSF). Unlike the chemical changes of black tea in fermentation, which are catalyzed by endogenous enzymes in tea leaves [3,4], the chemical changes in the SSF of PFPT are catalyzed by the microbial enzymes [1]. Presently, the SSF of PFPT is a natural fermentation without the use of starter cultures or the sterilization of raw materials. This gives rise to the growth of diverse microorganisms that may be primarily involved in the development of the different tastes, flavors, and health benefits of PFPT. Therefore an in-depth knowledge of the diversity and dynamics of the microbiota and changes in tea compounds in the SSF of PFPT is essential to understanding the formation of the characteristic properties of PFPT, and to develop industrial starters and control systems.

The diversity of microbiota in SSF was investigated by culture methods and many microbial species belonging to a variety of families have been identified, such as Aspergillaceae, Bacillaceae, Chaetomiaceae, etc. [7]. Additionally, a high level of microbiota diversity was gained using culture-independent approaches, such as denaturing gradient gel electrophoresis (PCR-DGGE) [8-11], a $16 S$ rRNA gene clonal library [7], and pyrosequencing analyses [12,13]. Recently, we investigated the microbial communities and enzymes of an SSF processing sample of PFPT (collected on day 21) using 454 pyrosequencing and LC-MS/MS approaches [13]. The microbiome and 25 toxic metabolites in fermented Pu-erh tea were investigated by Illumina MiSeq platform (Illumina, Inc., SanDiego, CA, USA) and a quantitative multiplex metabolite analysis [14]. However, the dynamics of the microbiota in SSF had only investigated by PCR-DGGE $[8,10,11]$ and a $16 S$ rRNA gene clonal library [7]. Thus, further studies using Next-Generation Sequencing were necessary. Additionally, several reports, such as those by Gong [15], Lee [16], and Qin [17], evaluated the changes in the chemical compounds during the SSF of PFPT. None of these studies established the influence of the successive microbial populations on the changes in the tea's chemical components during the SSF of PFPT.

In this work, the microbial succession and dynamics of the tea's characteristic chemical compounds in the SSF of PFPT were studied, and the relationship between microbiota and changes in tea compounds was surveyed. This research provides a foundation for further comprehensive studies on the formation of the special properties of PFPT and for the development of industrial starters.

\section{Materials and Methods}

\subsection{Pu-erh Tea Fermentation and Sample Collection}

The SSF of PFPT in this work was developed according to the traditional method, which is a natural fermentation. The raw materials, water, utensils, and environment were not sterilized, and a starter was not used. Sun-dried green tea, used as the raw material for the SSF of PFPT, was purchased from Puer City, Yunnan Province, China. Two repeated SSFs were performed in our laboratory at Kunming City, Yunnan Province, China. A 30-kg sample of the sun-dried green tea leaves was mixed with $15 \mathrm{~L}$ of tap water to produce a solid content of $\sim 65 \%(w / v)$.The leaves were mixed every seven days to ensure homogeneity, and tap water was added to keep the solids content at $65 \%-75 \%$ (as judged by the experience of the manufacturer). When the fermented tea mass was reddish-brown and free from an astringent taste ( $\sim 35$ days), the tea leaves were air-dried to a water content of $\sim 10 \%$, and the fermentation process was stopped. Samples of tea leaves were collected every seven days and divided into two parts: one was air-dried and subjected to sensory evaluation according to the protocol described by GB/T 23776-2009 [18] and analyses of the tea's chemical compounds, and the other was stored at $-80^{\circ} \mathrm{C}$ for 454 pyrosequencing analyses.

\subsection{Analysis of PFPT's Chemical Compounds}

The contents of the tea polyphenols (TPs) and free amino acids (FAA) were determined by the spectrophotometric method based on $\mathrm{FeSO}_{4}$ and the ninhydrin assay method described by 
Liang et al. [19], respectively. The main tea pigments, including theabrownin (TB), theaflavin (TF), and thearubigin (TR), were analyzed using the spectrophotometric method described by Wang et al. [20]. The contents of gallic acid (GA), caffeine (CAF), 1,4,6-tri-O-galloyl- $\beta$-D-glucose (GG), and catechins, including (+)-catechin (C), (-)-epicatechin (EC), (-)-epigallocatechin (EGC), (-)-epicatechin 3-O-gallate (ECG), and (-)-epigallocatechin 3-O-gallate (EGCG) in tea leaves was determined by high-performance liquid chromatography (HPLC) using an Agilent 1200 series HPLC system consisting of an LC-20AB solvent delivery unit, a SIL-20A autosampler, a CTO-20A column oven, a G1314B VWD (280 nm), and an LC Ver1.23 workstation (Agilent Technologies, Palo Alto, CA, USA). Separation was completed using the TSK-GEL ODS-80TM column $(4.6 \mathrm{~mm}$ i.d. $\times 250 \mathrm{~mm}$, Tosoh, Yamaguchi, Japan). The mobile phases were solvents $\mathrm{A}\left(0.05 \mathrm{M} \mathrm{H}_{3} \mathrm{PO}_{4}-\mathrm{H}_{2} \mathrm{O}, 5 \% \mathrm{CH}_{3} \mathrm{CN}\right)$ and $\mathrm{B}\left(0.05 \mathrm{M} \mathrm{H}_{3} \mathrm{PO}_{4}-\mathrm{H}_{2} \mathrm{O}, 80 \% \mathrm{CH}_{3} \mathrm{CN}\right)$. Elution conditions and flow rates were: $0-25 \mathrm{~min}$, solvent $\mathrm{A}$ was reduced from $95 \%$ to $55 \%$ and B from $5 \%$ to $45 \%$ (linear gradient); $26 \mathrm{~min}$, solvent $\mathrm{B}$ increased to $100 \%$; $26-31 \mathrm{~min}$, solvent B was kept at 100\%; 31-32 min, solvent A increased from $0 \%$ to $95 \%$; and from 32-38 min, solvent $\mathrm{A}$ was kept at $95 \%$; the flow rate was $1.0 \mathrm{~mL} / \mathrm{min}$. The temperature of the column oven was maintained at $40^{\circ} \mathrm{C}$. The injection volume was $10 \mu \mathrm{L}$. The chemical compounds were identified in the tea liquids by comparing the retention times of the peaks with those of the standards. Each tea sample was extracted twice and each extraction was analyzed twice.

\subsection{Enumeration of Microorganisms in SSF of PFPT}

Tea leaves $(25 \mathrm{~g}$ ) were suspended in $225 \mathrm{~mL}$ of $0.9 \% \mathrm{NaCl}$ buffer. The liquids were serially diluted, and the diluted samples were spread on Rose Bengal Medium Agar (5 g peptone, $10 \mathrm{~g}$ glucose, $1 \mathrm{~g}$ $\mathrm{KH}_{2} \mathrm{PO}_{4}, 0.5 \mathrm{~g} \mathrm{MgSO}_{4} \cdot 7 \mathrm{H}_{2} \mathrm{O}$, and $20 \mathrm{~g}$ Agar per liter) containing $0.1 \mathrm{~g} / \mathrm{L}$ chloramphenicol and on nutrient agar (NA) (5 g peptone, $3 \mathrm{~g}$ beef extract, $5 \mathrm{~g} \mathrm{NaCl}$ and $20 \mathrm{~g}$ agar/L) plates for fungal and bacterial enumerations, respectively. The Rose Bengal Medium Agar and NA plates were incubated at $28^{\circ} \mathrm{C}$ for 5 days and $37^{\circ} \mathrm{C}$ for two days, and the numbers of microorganisms in fermented tea leaves were calculated as colony-forming units $(\mathrm{CFU}) / \mathrm{g}$.

\subsection{Pyrosequencing Analysis}

DNA extraction, PCR amplification, amplicon quantitation, pyrosequencing, and data analysis were developed at Majorbio Bio-Pharm Technology Co., Ltd. (Shanghai, China) on a Roche Genome Sequencer GS-FLX Titanium platform (Roche Diagnostics, Basel, Switzerland) using MOTHUR software version 1.34 [21,22]. DNA from fermented tea leaves was extracted using the E.Z.N.A. ${ }^{\mathrm{TM}}$ Soil DNA Kit (Omega Bio-Tek, Norcross, GA, USA) according to the manufacturer's instructions. The TransGen AP221-02 kit with TransStart Fastpfu DNA polymerase (TransGen Biotech, Beijing, China) was used in PCR reactions. To analyze the taxonomic composition of the bacterial and fungal community, universal primer pairs of 27F (5'-AGAGTTTGATCCTGG CTCAG-3') with 533R (5'-TTA CCG CGG CTG GCA C-3'), and ITS1 (5'-TCCGTAGGTGAACCT GCGG-3') with ITS4 ( $5^{\prime}$-TCCTCCGCTTATTGATATGC-3'), incorporating FLX titanium adapters, which targeted the V1-V3 region of the bacterial $16 S r R N A$ gene, and the ITS region of the fungal 18S $r R N A$ gene, were chosen for the amplification and subsequent pyrosequencing of the PCR products, respectively. Each PCR reaction consisted of $0.4 \mu \mathrm{L}$ Fastpfu DNA polymerase, $4 \mu \mathrm{L}$ five-fold Fastpfu Buffer, $2 \mu \mathrm{L} 2.5 \mathrm{mM}$ dNTPs, $0.8 \mu \mathrm{L}$ of each primer, $10 \mathrm{ng}$ of DNA, and $\mathrm{ddH}_{2} \mathrm{O}$ to a final concentration of $20 \mu \mathrm{L}$. The amplification program for the bacterial $16 S$ rRNA gene consisted of an initial denaturation step at $95^{\circ} \mathrm{C}$ for $2 \mathrm{~min}$. This was followed by 25 cycles, where a cycle consisted of $95^{\circ} \mathrm{C}$ for $30 \mathrm{~s}$ (denaturation), $55^{\circ} \mathrm{C}$ for $30 \mathrm{~s} \mathrm{(annealing),} \mathrm{and} 72{ }^{\circ} \mathrm{C}$ for $30 \mathrm{~s} \mathrm{(extension),} \mathrm{followed} \mathrm{by} \mathrm{a} \mathrm{final} \mathrm{extension} \mathrm{of} 72{ }^{\circ} \mathrm{C}$ for $5 \mathrm{~min}$. The amplification program for the fungal $18 \mathrm{~S} r R N A$ gene consisted of an initial denaturation step at $95^{\circ} \mathrm{C}$ for $2 \mathrm{~min}$. This was followed by 30 cycles, where a cycle consisted of $95^{\circ} \mathrm{C}$ for $30 \mathrm{~s}$ (denaturation), $55^{\circ} \mathrm{C}$ for $30 \mathrm{~s}$ (annealing), and $72{ }^{\circ} \mathrm{C}$ for $30 \mathrm{~s}$ (extension), followed by a final extension of $72{ }^{\circ} \mathrm{C}$ for $5 \mathrm{~min}$. All PCR products were visualized on agarose gels ( $2 \%$ in TBE buffer) containing ethidium bromide. For each sample, three independent PCRs were performed. The triplicate products were pooled and 
purified using an AxyPrep PCR Clean-up Kit (Axygen Biosciences, Axygen, CA, USA). The DNA concentration of each PCR product was determined using a Quant-iT PicoGreen double-stranded DNA assay (Invitrogen, Carlsbad, CA, USA) and was quality controlled on an Agilent 2100 bioanalyzer (Agilent Technologies, Palo Alto, CA, USA). Amplicon pyrosequencing was performed from the A-end using a 454/Roche A sequencing primer kit on a Roche Genome Sequencer GS-FLX Titanium platform at Majorbio Bio-Pharm Technology Co., Ltd.

Data preprocessing was performed mainly using MOTHUR software [21,22]. The chimeric sequences were excluded using the chimera.uchime command with default parameters [23]. Sequences with similarities $>97 \%$ were clustered into one operational taxonomic unit (OTU) using MOTHUR. The taxonomical assignment of each OTU was performed using the classify.seqs command (Naïve Bayesian Classifier) against the SILVA $16 \mathrm{~S}$ rRNA gene database (release 111) at an $80 \%$ confidence level [24-26]. Community richness and diversity indices (Chao1 estimator, abundance-based coverage estimator (ACE) and Shannon indices, respectively) and rarefaction curves were obtained using MOTHUR [27].

To compare microbial community structures based on the OTU composition across all samples, a principal component analysis (PCA) was carried out using the SPSS software package (SPSS 19.0, Chicago, IL, USA).

The 454 pyrosequencing data generated for this study were submitted to the Sequence Read Archive (SRA) and are available under projects SRR1634067 and SRR1633201. The representative $16 S$ rRNA gene sequences of isolated bacteria in this study were deposited in GenBank under accession numbers KP732727-KP732737.

\subsection{Statistical Analyses}

In the analysis of tea chemical compounds, each tea sample was extracted twice, and each extraction was analyzed twice. A one-way ANOVA was used to identify statistical differences, followed by the least-significant difference method for paired data. Results are expressed as the mean \pm SD. Pearson correlation coefficients between tea chemical compounds and abundant genera were calculated. All of the data were analyzed using SPSS 19.0 software packages (SPSS Inc., Chicago, IL, USA), and $p<0.05$ was considered to be significant.

\section{Results and Discussion}

\subsection{SSF of PFPT, Sample Collection, and Variations in Chemical Compounds}

To better understand the natural SSF of traditional Chinese PFPT, laboratory fermentation was developed and repeated twice. Every seven days, tea leaf samples were collected and subjected to sensory evaluation (Figure 1). After SSF, the tea leaves became dark, the tea liquid became reddish-brownish, and the fermented tea leaves became softer than those of the raw material. The contents of chemical compounds of tea leaves are listed in Table 1. After SSF, the levels of TPs, FAA, EGC, EC, EGCG, GG, ECG, GA, TF, and TR decreased significantly $(p<0.05)$, and contents of TB increased significantly $(p<0.05)$. These changes in the chemical compounds during the SSF of PFPT were in accord with the previous reports of Gong [15], Lee [16], and Qin [17]. It was hypothesized that microbiota led to these chemical changes. However, the influence of microbial populations on the changes of tea chemical components during SSF of PFPT is not established. So we developed the further research to survey the diversity and dynamic of microbiota and change of tea compounds. 
Table 1. Variation of levels of chemical compounds during solid-state fermentation (SSF) of Post-fermented Pu-erh tea (Pu-erh Shucha, PFPT).

\begin{tabular}{|c|c|c|c|c|c|c|c|}
\hline \multirow{2}{*}{$\begin{array}{l}\text { Chemical } \\
\text { Compounds }\end{array}$} & \multicolumn{6}{|c|}{ Sample of Tea Leaves Collected During SSF of PFPT } & \multirow{2}{*}{ Variation Trend } \\
\hline & 0 Day & 7 Day & 14 Day & 21 Day & 28 Day & 35 Day & \\
\hline TPs $(\%)$ & $37.86 \pm 1.72^{a}$ & $31.55 \pm 2.64^{b}$ & $22.63 \pm 1.47^{c}$ & $15.71 \pm 0.67^{\mathrm{d}}$ & $12 \pm 0.33^{\mathrm{e}}$ & $10.56 \pm 0.78^{\mathrm{e}}$ & decreasing $(p<0.05)$ \\
\hline FAA (\%) & $2.52 \pm 0.02^{\mathrm{a}}$ & $2 \pm 0.03 \mathrm{~b}$ & $1.47 \pm 0.15^{c}$ & $1.01 \pm 0.09 \mathrm{~d}$ & $0.93 \pm 0.15^{\mathrm{d}}$ & $0.62 \pm 0.23 \mathrm{e}$ & decreasing $(p<0.05)$ \\
\hline $\mathrm{EGC}(\mathrm{mg} / \mathrm{g})$ & $29.60 \pm 7.94$ aa & $47.41 \pm 8.28^{\mathrm{bb}}$ & $33.65 \pm 6.67$ aа & $15.89 \pm 6.06^{\mathrm{cc}}$ & $11.46 \pm 2.51^{\mathrm{cd}}$ & $6.97 \pm 1.74 \mathrm{de}$ & increasing ( $0-7$ day, $p<0.05)$, decreasing $(7-35 \mathrm{~d}$ \\
\hline $\mathrm{C}(\mathrm{mg} / \mathrm{g})$ & $9.83 \pm 0.76^{\mathrm{a}}$ & $5.68 \pm 1.17^{b}$ & $4.49 \pm 0.42^{\mathrm{c}}$ & $3.02 \pm 0.77^{\mathrm{d}}$ & $2.02 \pm 0.71^{\mathrm{e}}$ & $1.69 \pm 0.60^{\mathrm{e}}$ & decreasing $(0-21$ day, $p<0.05)$ \\
\hline $\mathrm{EC}(\mathrm{mg} / \mathrm{g})$ & $13.70 \pm 0.12^{\mathrm{a}}$ & $27.48 \pm 0.62^{b}$ & $17.54 \pm 4.36^{\mathrm{c}}$ & $11.44 \pm 2.22^{\mathrm{a}}$ & $6.05 \pm 0.94^{\mathrm{d}}$ & $2.84 \pm 0.78^{\mathrm{e}}$ & increasing $(0-7$ day, $p<0.05)$, decreasing $(7-35$ day, $p<0.05)$ \\
\hline EGCG $(\mathrm{mg} / \mathrm{g})$ & $59.73 \pm 1.82^{\mathrm{a}}$ & $11.54 \pm 3.57^{b}$ & $7.15 \pm 2.98^{c}$ & $2.86 \pm 0.93^{\mathrm{d}}$ & $1.39 \pm 0.61 \mathrm{~d}$ & $1.04 \pm 1.41^{\mathrm{d}}$ & decreasing $(0-21$ day, $p<0.05)$ \\
\hline GG (mg/g) & $4.19 \pm 0.22^{\mathrm{a}}$ & $0.95 \pm 0.34^{\mathrm{b}}$ & $0.90 \pm 0.14^{b}$ & $0.67 \pm 0.22^{c}$ & $0.53 \pm 0.17^{c}$ & $0.45 \pm 0.16^{c}$ & decreasing $(0-21$ day, $p<0.05)$ \\
\hline $\mathrm{ECG}(\mathrm{mg} / \mathrm{g})$ & $39.63 \pm 1.35^{\mathrm{a}}$ & $6.69 \pm 2.52^{b}$ & $4.13 \pm 1.26^{\mathrm{c}}$ & $2.04 \pm 0.83^{\mathrm{d}}$ & $0.72 \pm 0.32$ de & $0.57 \pm 0.33^{\text {ee }}$ & decreasing $(0-21$ day, $p<0.05)$ \\
\hline $\mathrm{CAF}(\mathrm{mg} / \mathrm{g})$ & $28.50 \pm 0.18^{a}$ & $29.53 \pm 0.86^{\mathrm{a}}$ & $32.09 \pm 6.52^{a}$ & $30.25 \pm 3.36^{a}$ & $30.00 \pm 1.66^{\mathrm{a}}$ & $30.51 \pm 1.75$ a & no significant change $(p>0.05)$ \\
\hline $\mathrm{TF}(\%)$ & $0.35 \pm 0.01^{\mathrm{a}}$ & $0.53 \pm 0.07^{b}$ & $0.45 \pm 0.03^{b}$ & $0.34 \pm 0.08^{c}$ & $0.25 \pm 0.08^{\mathrm{d}}$ & $0.22 \pm 0.02^{\mathrm{d}}$ & increasing $(0-7$ day, $p<0.05)$, decreasing $(7-35$ day, $p<0.05)$ \\
\hline TR (\%) & $7.01 \pm 0.08^{\mathrm{a}}$ & $7.78 \pm 0.7^{b}$ & $7.48 \pm 0.44^{b}$ & $5.97 \pm 0.08^{c}$ & $5.12 \pm 0.46^{\mathrm{d}}$ & $2.65 \pm 0.6^{\mathrm{e}}$ & increasing $(0-7$ day, $p<0.05)$, decreasing $(7-35$ day, $p<0.05)$ \\
\hline ТВ $(\%)$ & $3.23 \pm 0.08^{\mathrm{a}}$ & $4.16 \pm 0.21^{\mathrm{a}}$ & $7.19 \pm 0.49^{b}$ & $11.32 \pm 0.87^{c}$ & $13.38 \pm 1.72^{\mathrm{d}}$ & $15.14 \pm 2.22 \mathrm{e}$ & increasing $(p<0.05)$ \\
\hline
\end{tabular}

Note: Different lowercase letters in superscript $(\mathrm{a}, \mathrm{b}, \mathrm{c}, \mathrm{d}$ and $\mathrm{e})$ in a same row indicate levels of chemical compounds with statistically significant difference ( $p<0.05)$, by one-way ANOVA. 

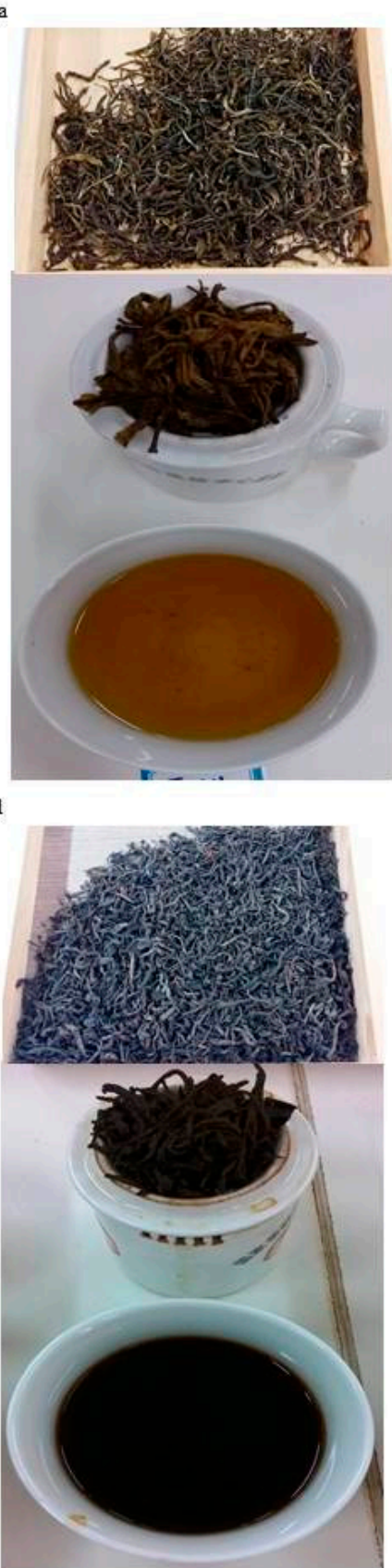

$\mathrm{b}$
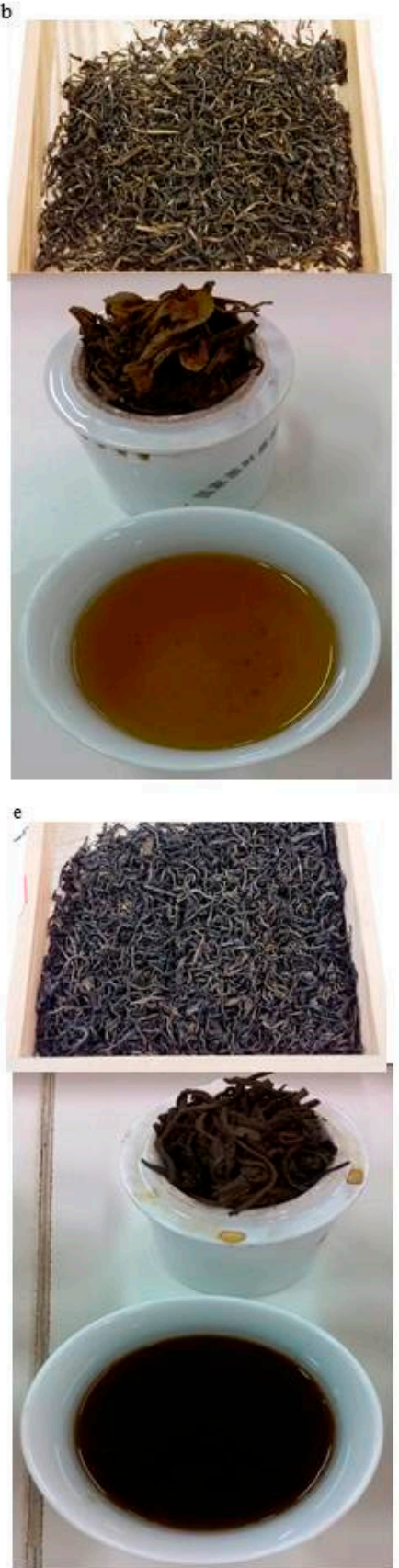
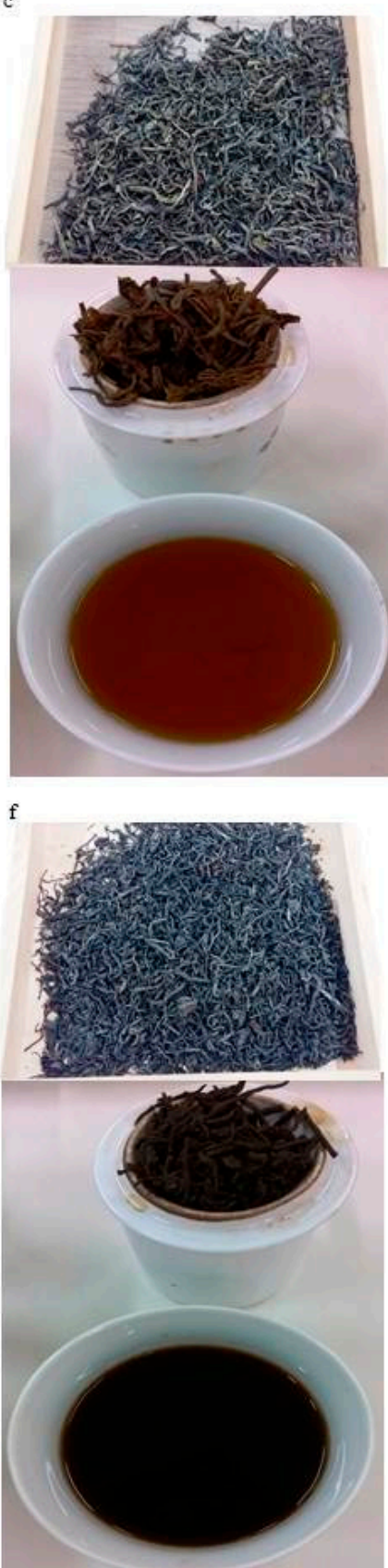

Figure 1. The representative sensory evaluation of tea leaves collected on day 0 (a); 7 (b); 14 (c); 21 (d); 28 (e) and 35 (f) during solid-state fermentation (SSF) of Post-fermented Pu-erh tea (Pu-erh Shucha, PFPT). The sensory evaluation was developed according the Chinese standard (GB/T 23776-2009) as follows: $3 \mathrm{~g}$ of dried tea leaves were infused in $150 \mathrm{~mL}$ boiled water for $5 \mathrm{~min}$; the pre-and post-infusion tea leaves and the tea liquid after infusion are shown.

\subsection{Diversity of Microbial Communities during SSF of PFPT}

The average initial bacterial and fungal cell numbers in the raw material were approximately $5.7 \times 10^{2}$ and $1.3 \times 10^{3} \mathrm{CFU} / \mathrm{g}$, which increased to about $5.8 \times 10^{7}$ and $3.2 \times 10^{6} \mathrm{CFU} / \mathrm{g}$ at seven days of fermentation, and then increased to about $10^{8}$ or $10^{7} \mathrm{CFU} / \mathrm{g}$ during SSF (Table 2). 
Table 2. Summary of pyrosequencing analyses of the bacterial $16 S r R N A$ and fungal $18 S r R N A$ genes.

\begin{tabular}{|c|c|c|c|c|c|c|c|c|c|c|c|}
\hline \multirow[t]{2}{*}{ Sample } & \multirow{2}{*}{$\begin{array}{c}\text { Cell Number } \\
\text { Means of CFU/g }\end{array}$} & \multirow[t]{2}{*}{$\begin{array}{l}\text { No. of } \\
\text { Reads }\end{array}$} & \multirow[t]{2}{*}{$\begin{array}{l}\text { No. of } \\
\text { OTUs }\end{array}$} & \multirow[t]{2}{*}{$\begin{array}{c}\text { Coverage } \\
(\%)\end{array}$} & \multicolumn{3}{|c|}{ No. of Taxonomic Groups Identified } & \multicolumn{2}{|c|}{ Richness Estimators } & \multicolumn{2}{|c|}{ DIVERSITY Indices } \\
\hline & & & & & Phylum & Family & Genus & ACE & Chao1 & Shannon-Weaver Index & Simpson \\
\hline \multicolumn{12}{|c|}{ Bacteria } \\
\hline D-0-1 & \multirow{2}{*}{$5.7 \times 10^{2}$} & 5409 & 1338 & 81.94 & 7 & 44 & 80 & 8429 & 4495 & 4.84 & 0.07 \\
\hline $\mathrm{D}-0-2$ & & 5529 & 1482 & 78.60 & 8 & 55 & 106 & 9935 & 5343 & 5.30 & 0.04 \\
\hline D-7-1 & \multirow[b]{2}{*}{$5.8 \times 10^{7}$} & 4637 & 1479 & 75.57 & 14 & 90 & 158 & 10,208 & 5487 & 5.52 & 0.03 \\
\hline D-7-2 & & 6691 & 1988 & 77.18 & 10 & 84 & 111 & 15,638 & 7076 & 5.50 & 0.04 \\
\hline D-14-1 & \multirow{2}{*}{$1.7 \times 10^{8}$} & 4539 & 1099 & 84.27 & 7 & 60 & 95 & 4567 & 2999 & 5.43 & 0.03 \\
\hline D-14-2 & & 5393 & 2307 & 69.63 & 12 & 86 & 152 & 12,646 & 6382 & 6.91 & 0.01 \\
\hline D-21-1 & \multirow{2}{*}{$1.2 \times 10^{8}$} & 3472 & 1302 & 73.30 & 5 & 38 & 63 & 7453 & 3622 & 5.90 & 0.03 \\
\hline $\mathrm{D}-21-2$ & & 5811 & 2071 & 75.17 & 10 & 59 & 92 & 10,983 & 6042 & 6.57 & 0.01 \\
\hline D-28-1 & \multirow{2}{*}{$2.0 \times 10^{8}$} & 3175 & 1261 & 71.28 & 6 & 53 & 76 & 7165 & 3621 & 5.97 & 0.02 \\
\hline D-28-2 & & 3649 & 1178 & 76.38 & 7 & 57 & 85 & 6782 & 3989 & 5.34 & 0.04 \\
\hline D-35-1 & \multirow{2}{*}{$8.3 \times 10^{7}$} & 3119 & 1138 & 73.45 & 5 & 51 & 81 & 5953 & 3319 & 5.66 & 0.02 \\
\hline D-35-2 & & 3137 & 948 & 78.39 & 7 & 52 & 77 & 5157 & 2687 & 4.96 & 0.06 \\
\hline \multicolumn{12}{|c|}{ Fungi } \\
\hline D-0-1 & \multirow[b]{2}{*}{$1.3 \times 10^{3}$} & 2189 & 162 & 96.62 & 5 & 41 & 58 & 330 & 258 & 2.6 & 0.26 \\
\hline D-0-2 & & 1395 & 92 & 97.56 & 5 & 27 & 36 & 127 & 127 & 2.27 & 0.31 \\
\hline D-7-1 & \multirow{2}{*}{$3.2 \times 10^{6}$} & 6305 & 32 & 99.71 & 3 & 3 & 4 & 128 & 63 & 0.4 & 0.84 \\
\hline D-7-2 & & 5773 & 30 & 99.65 & 3 & 3 & 4 & 261 & 125 & 0.29 & 0.89 \\
\hline D-14-1 & \multirow[b]{2}{*}{$9.0 \times 10^{7}$} & 5718 & 41 & 99.56 & 2 & 3 & 3 & 184 & 116 & 0.98 & 0.48 \\
\hline D-14-2 & & 5737 & 33 & 99.65 & 3 & 3 & 3 & 293 & 128 & 0.65 & 0.71 \\
\hline D-21-1 & \multirow{2}{*}{$9.6 \times 10^{7}$} & 6211 & 41 & 99.60 & 2 & 2 & 3 & 270 & 101 & 0.50 & 0.79 \\
\hline D-21-2 & & 5487 & 61 & 99.42 & 2 & 3 & 4 & 193 & 123 & 1.10 & 0.47 \\
\hline D-28-1 & \multirow{2}{*}{$1.2 \times 10^{8}$} & 5314 & 66 & 99.36 & 2 & 11 & 13 & 180 & 136 & 0.66 & 0.78 \\
\hline D-28-2 & & 5955 & 49 & 99.63 & 4 & 3 & 4 & 114 & 67 & 0.66 & 0.75 \\
\hline D-35-1 & \multirow[b]{2}{*}{$6.6 \times 10^{7}$} & 8050 & 99 & 99.30 & 2 & 6 & 9 & 325 & 195 & 0.78 & 0.75 \\
\hline D-35-2 & & 5199 & 67 & 99.29 & 2 & 4 & 5 & 248 & 123 & 0.87 & 0.69 \\
\hline
\end{tabular}


The microbial communities were analyzed using a pyrosequencing-based analysis of the bacterial $16 S r R N A$ gene and fungal $18 S$ rRNA gene in the 12 samples of fermented tea leaves. After removing low-quality and chimeric sequences, a total of 54,561 bacterial and 63,333 fungal high quality sequences with average read lengths of 472 and $497 \mathrm{bp}$, respectively, were obtained. Each bacterial library contained 3119-6691 reads, with different phylogenetic OTUs ranging from 948 to 2307, which were classified into 5-14 phyla, 38-90 families and 63-158 genera (Table 2). In them, 15,490 sequences were classified as cyanobacteria, which are probably chloroplast sequences that originated from the tea plant. These sequences were removed prior to further analysis. Each fungal library contained 1395-8050 reads, with different phylogenetic OTUs ranging from 30 to 162, and was classified into 2-5 phyla, 2-41 families, and 3-58 genera (Table 2).

Rarefaction curves at a 3\% cutoff are shown in Figure 2, and the Chao1 estimator, abundance-based coverage estimator (ACE), and Shannon index are listed in Table 2. The bacterial diversity indices were significantly greater than that of fungi $(p<0.05)$, the bacterial rarefaction curve did not approach a plateau at a similar level, and more bacterial taxonomic groups were identified, demonstrating that bacterial communities in fermented tea leaves have a high diversity level. The fungal diversity indices in raw material (day 0) was significantly greater than that of fermented tea leaves (day 7-35) $(p<0.05$ ), indicating that a decrease of fungal diversity during SSF. This decrease of fungal diversity was also reported by Zhang et al., recently [14]. It seems that as soon as water is added to start the fermentation, the fungal diversity decreased.
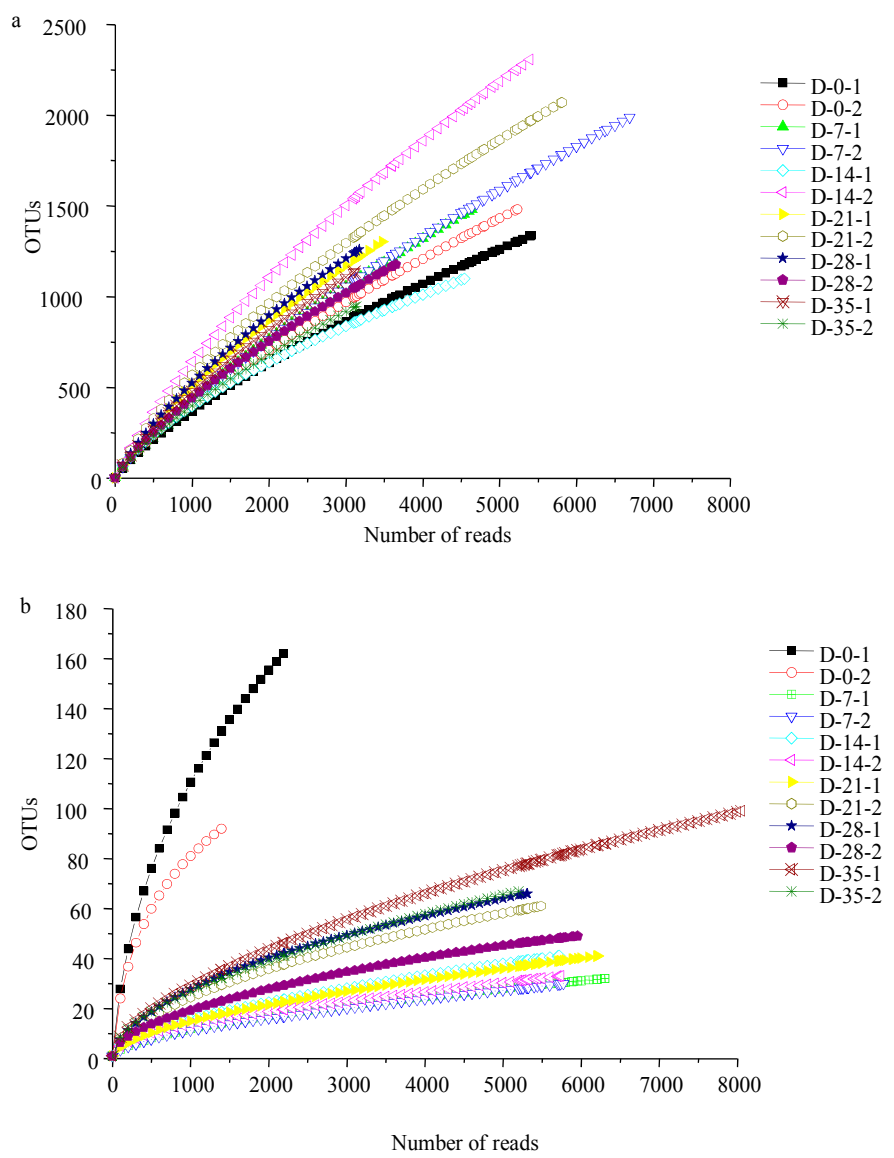

Figure 2. Rarefaction curve analyses of the $16 S r R N A$ gene (a) and $18 S r R N A$ gene (b) of the bacterial and fungal communities, respectively, present in the SSF of PFPT. Operational taxonomic units (OTUs) are defined as sequences sharing $97 \%$ nucleotide sequence similarity. 


\subsection{Dynamics and Source of Bacteria during SSF of PFPT}

A heat map of major bacteria $(>1 \%)$ in tea leaves at the genus level is given in Figure 3a. A PCA analysis is shown in Figure 3b. The bacterial community in the raw material (day 0 ) was different from those in other samples, with dominant bacteria of Sphingobacterium (16.48\%) and Methylobacterium $(16.39 \%)$. After seven days of fermentation, the dominant bacteria had changed to Pantoea (21.32\%) and Pseudomonas (18.87\%). In the 14 days of SSF, the genera of Paenibacillus and Bacillus were dominant and accounted for $26.21 \%$ and $16.73 \%$ of total reads, respectively. Achromobacter (17.62\%) was dominant at 21 days. In the sample collected on day 28 of SSF, the dominant bacteria were identified as Staphylococcus (20.78\%) and no_rank_Dermabacteraceae (16.91\%). At the last stage of SSF (day 35), no_rank_Dermabacteraceae (30.82\%) were dominant, followed by Staphylococcus (19.62\%). At the phylum level, the pyrosequencing analysis indicated that the dominant bacteria were Proteobacteria, Firmicutes and Actinobacteria. By metagenomic analysis, Lyu showed that dominant bacteria in one fermented sample of PFPT were Proteobacteria (23.56\%), Actinobacteria (23.35\%), and Firmicutes (11.37\%) [12]. By using a 16S rRNA gene clone library, we also demonstrated that the dominant bacteria during SSF of PFPT were Proteobacteria and Firmicutes [7]. Recently, Zhang identified that the most commonly observed bacterial taxa in $31 \mathrm{Pu}$-erh tea samples belonged to Firmicutes, Actinobacteria, and Proteobacteria [14]. These samples in different reports have similar dominant bacteria, suggesting that Proteobacteria, Firmicutes, and Actinobacteria may be the core bacteria in SSF of PFPT, and they may play crucial roles in the quality formation of the PFPT. However, more samples from different areas and producers should be investigated to validate this hypothesis.

To investigate the sources of the bacteria, a series of comparisons of major bacteria $(>1 \%)$ at the genus level were performed (Figure 4). A comparison of raw material and the seven-day fermented sample showed that they shared six bacterial genera, which accounted for $67.79 \%$ of the total reads of seven-day fermentation (Figure 4a). This revealed that partial bacteria in initial stages of SSF came from the raw material. Additionally, four genera were newly detected in the seven-day fermented sample. This demonstrated that a portion of the bacteria came from the fermentation environment (room, air, or water). Comparisons of bacterial genera between the samples of day 7 and 14, day 14 and 21, and day 21 and 28 showed that six, six, and five genera, respectively, accounting for $55.49 \%, 18.61 \%$, and $26.89 \%$, respectively, of each sample's reads were newly detected. A comparison of 35-day-fermented tea leaves and raw material showed that they shared only $18.35 \%$ of bacteria (Figure $4 \mathrm{f}$ ). Together, these comparisons indicated that active bacteria were from the raw material and fermentation environment during the initial stages, and the bacteria in the fermentation environment continued to naturally inoculate into tea mass during the SSF. This primary comparison suggested that environmental bacteria are involved in the fermentation of PFPT; this is possibly the reason for the geographical characteristics of PFPT. 


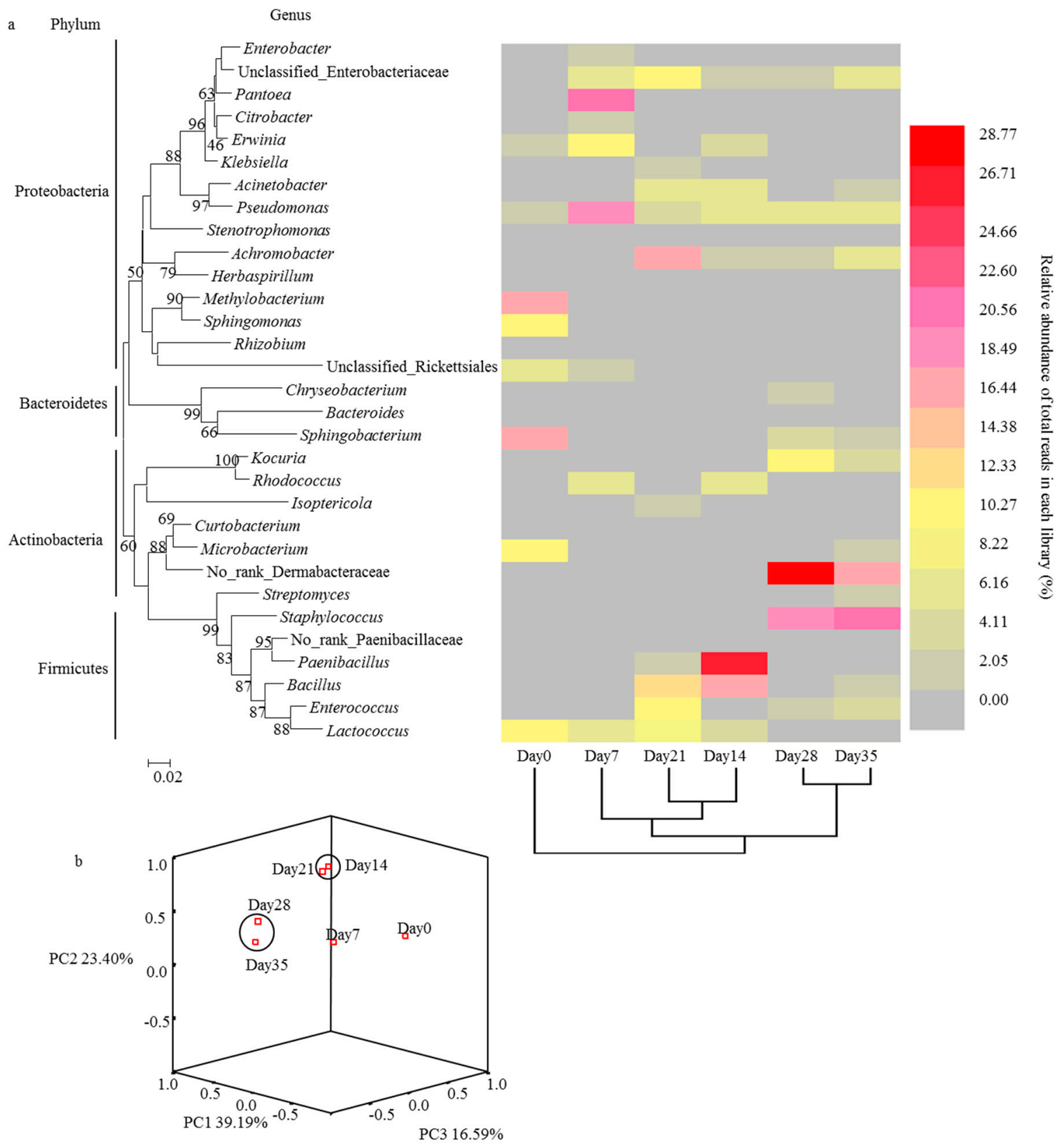

Figure 3. Heat map of relative abundances of major bacterial genera ( $>1 \%)$ (a); principal component analysis (PCA) analysis of bacterial communities in fermented tea leaves during the SSF of PFPT based on the relative abundances of the sample reads at the genus level $(\mathbf{b})$. 

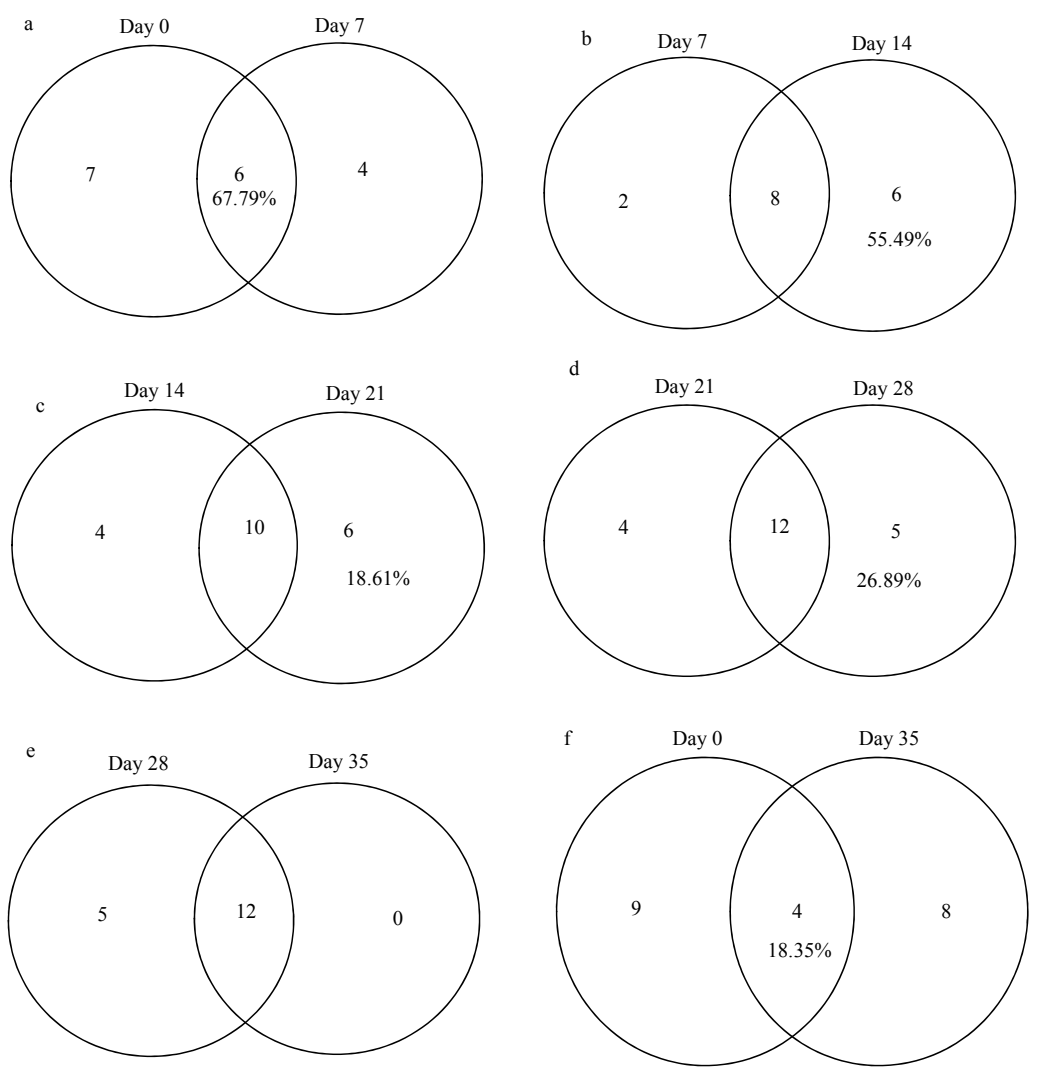

Figure 4. Comparisons of major bacteria $(>1 \%)$ at the genus level between day 0 and 7 (a); day 7 and 14 (b); day 14 and 21 (c); day 21 and 28 (d); day 28 and 35 (e); and day 0 and 35 (f) during the SSF of PFPT.

\subsection{Dynamics and Source of Fungi during SSF of PFPT}

In raw material, the dominant fungi were classified as no_rank_Fungi $(65.39 \%)$. When the water content of tea leaves was increased, the fungi belonging to Aspergillus were multiplied to dominate throughout the SSF process. They accounted for $94.08 \%, 74.79 \%, 79.27 \%, 93.76 \%$, and $95.79 \%$ of the total fungal community at day 7, 14, 21, 28, and 35, respectively. Additionally, fungi belonging to Rhizomucor multiplied and accounted for $3.73 \%$ at day 7 , and increased to $24.54 \%$ and $20.63 \%$ at day 14 and 21 , respectively, and then decreased to $3.07 \%$ at day 35 (Figure 5a). The differences in the dominant fungi between the raw material and fermented samples suggested a large shift in the fungal communities, which was corroborated by the separation of fungal communities in the raw material (day 0 ) from other fermenting samples (day 7, 14, 21, 28, and 35) in the PCA analysis (Figure 5b). The similarity in the dominant fungi in each fermented tea leaf sample suggests that fungal communities did not change significantly during the SSF of PFPT, and this was corroborated by the groupings of the fermented samples (day 7, 14, 21, 28, and 35) in the PCA analysis (Figure 5b). Fungi belonging to Aspergillus were identified as dominant throughout the SSF process of PFPT, and this corroborated previous reports that the major fungi involved in the SSF of PFPT were A. niger and B. adeninivorans [8], or A. niger, S. cerevisiae, and P. glabrum [11], and several Aspergillus spp. [1]. Comparisons of major fungi ( $>1 \%)$ at the genus level showed that they came from the raw material, suggesting that the raw materials were responsible for the active fungi. To our knowledge, this is the first work to survey the sources of the bacteria and fungi in the SSF of PFPT. 

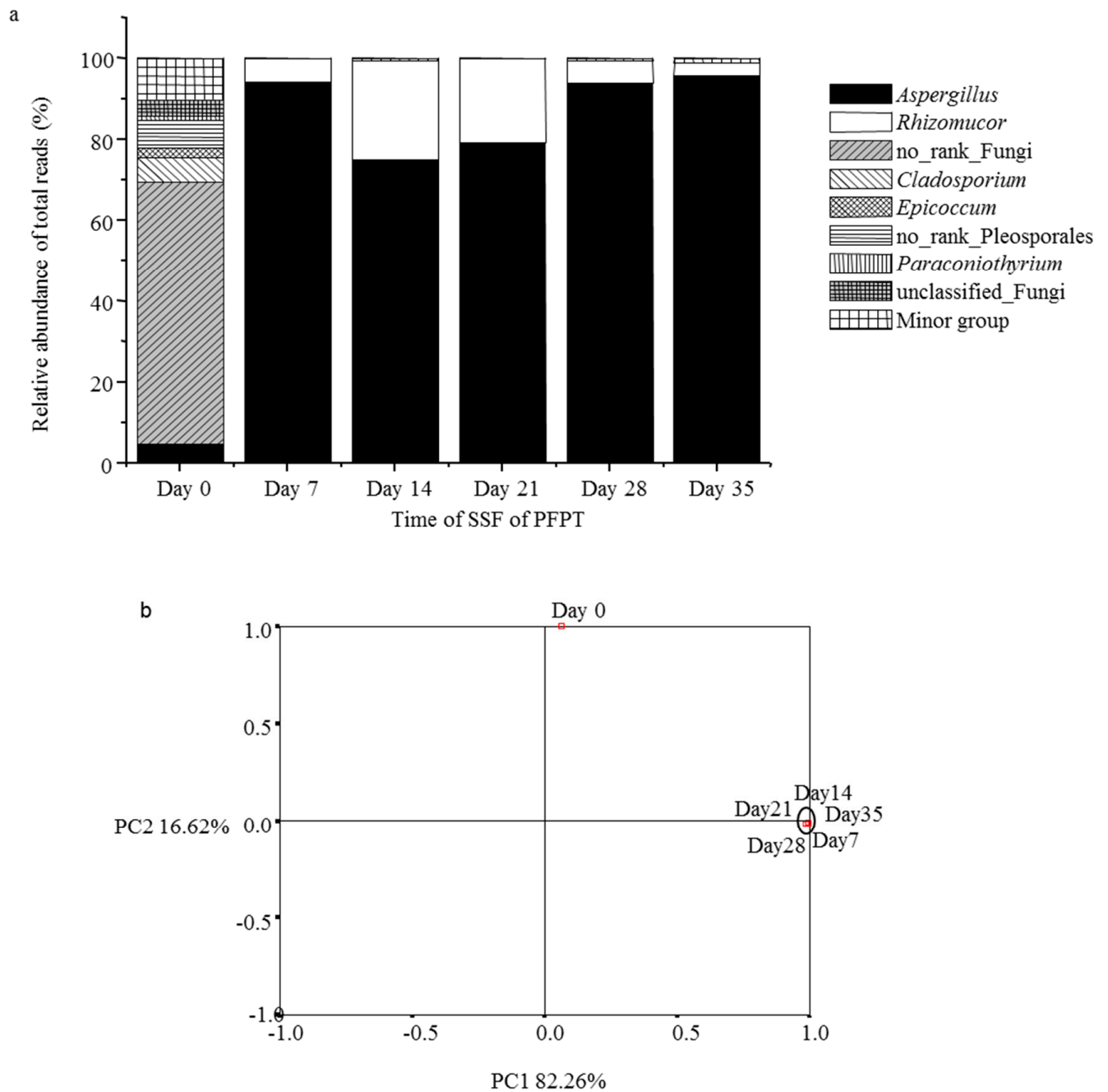

Figure 5. Fungal communities in tea leaves at the genus level during the SSF of PFPT (a); PCA analysis of fungal communities in fermented tea leaves during the SSF of PFPT based on the relative abundances of the sample reads at the genus level (b). Minor groups are composed of the parties showing a percentage of reads $<1.0 \%$ of the total reads in each sample.

\subsection{Correlations among Microbiota and Tea Components}

To explore microbial effects on tea components, correlations between chemical compounds and relative abundances of the bacterial and fungal genera were conducted and are shown in Tables 3-5. In total, 30 bacterial genera showed significant correlations to 1-8 tea compounds. For example, unclassified Actinobacteria have negative significant correlations to the contents of TPs, FAA, EGC, C, EC, TF, and TR; and have positive significant correlations to TB (Tables 3 and 4). For fungi, Aspergillus showed negative significant correlations to the contents of C, EGCG, ECG, and GG; OTUs assigned to no_rank_Fungi have positive significant correlations to the contents of C, EGCG, ECG, and GG; and Penicillium had positive significant correlations to the contents of EGCG, ECG, and GG (Table 5). The compounds had positive significant correlations to $2-10$ bacterial genera and showed negative significant correlations to $0-5$ bacterial genera (Table 3 ). This preliminary data suggested that microbiota with significant correlations to tea compounds may be involved in the dynamics of chemical compounds; however, the roles of these microbiota in the SSF of PFPT need further monoculture fermentation studies. 
Table 3. Significant correlation coefficients between the tea's chemical compounds and bacterial genera.

\begin{tabular}{|c|c|c|c|c|c|c|c|c|c|c|c|c|c|}
\hline Compounds & TPs & AA & CAF & EGC & c & EC & EGCG & GG & ECG & GA & TF & TR & TB \\
\hline \multirow[t]{10}{*}{$\begin{array}{l}\text { positive } \\
\text { significant } \\
\text { correlations }\end{array}$} & $\begin{array}{l}\text { Sphingomonas, } \\
0.745^{*}\end{array}$ & $\begin{array}{l}\text { Sphingomonas, } \\
0.774^{*}\end{array}$ & $\begin{array}{l}\text { Stenotrophomonas, } \\
0.873^{*}\end{array}$ & $\begin{array}{l}\text { Erwinia, } \\
0.955 \text { ** }\end{array}$ & $\begin{array}{l}\text { Sphingomonas, } \\
0.889^{* *}\end{array}$ & Erwinia, 0.957 ** & $\begin{array}{l}\text { Sphingobacterium, } \\
0.894^{* *}\end{array}$ & $\begin{array}{l}\text { Sphingobacterium, } \\
0.901 * *\end{array}$ & $\begin{array}{l}\text { Sphingobacterium, } \\
0.901 * *\end{array}$ & $\begin{array}{l}\text { Erwinia, } \\
0.948 \text { ** }\end{array}$ & Erwinia, 0.933 ** & Ervinia, $0.754 *$ & $\begin{array}{l}\text { Prevotella, } \\
0.771 \text { * }\end{array}$ \\
\hline & Rhizobium, $0.802 *$ & Rhizobium, 0.829 * & $\begin{array}{l}\text { Paenibacillus, } \\
0.831 \text { * }\end{array}$ & Pantoea, $0.792 *$ & Lactococcus, $0.741^{*}$ & Pantoea, $0.840 *$ & $\begin{array}{l}\text { Microbacterium, } \\
0.944^{* *}\end{array}$ & $\begin{array}{l}\text { Microbacterium, } \\
0.956 \text { ** }\end{array}$ & $\begin{array}{l}\text { Microbacterium, } \\
0.951 \text { ** }\end{array}$ & $\begin{array}{l}\text { Pseudomonas, } \\
0.791 \text { * }\end{array}$ & Pantoea, 0.765 * & $\begin{array}{l}\text { Enterobacter, } \\
0.758^{*}\end{array}$ & Kocuria, 0.808 * \\
\hline & Herbaspirillum, $0.774^{*}$ & $\begin{array}{l}\text { Herbaspirillum, } \\
0.797^{*}\end{array}$ & & $\begin{array}{l}\text { Enterobacter, } \\
0.825 *\end{array}$ & Rhizobium, 0.929 ** & $\begin{array}{l}\text { Enterobacter, } \\
0.912 * *\end{array}$ & $\begin{array}{l}\text { Sphingomonas, } \\
0.991^{* *}\end{array}$ & $\begin{array}{l}\text { Sphingomonas, } \\
0.995^{* *}\end{array}$ & $\begin{array}{l}\text { Sphingomonas, } \\
0.994^{* *}\end{array}$ & Pantoea, $0.839^{*}$ & $\begin{array}{l}\text { Enterobacter, } \\
0.943^{* *}\end{array}$ & $\begin{array}{l}\text { Streptococcus, } \\
0.829^{*}\end{array}$ & $\begin{array}{l}\text { Bacteroides, } \\
0.797^{*}\end{array}$ \\
\hline & $\begin{array}{l}\text { Chryseobacterium, } \\
0.862^{*}\end{array}$ & $\begin{array}{l}\text { Chryseobacterium, } \\
0.880^{*}\end{array}$ & & $\begin{array}{l}\text { Rhodococcus, } \\
0.851^{*}\end{array}$ & $\begin{array}{l}\text { Herbaspirillum, } \\
0.906^{* *}\end{array}$ & $\begin{array}{l}\text { Rhodococcus, } \\
0.848^{*}\end{array}$ & $\begin{array}{l}\text { Rhizobium, } \\
0.992^{* *}\end{array}$ & $\begin{array}{l}\text { Rhizobium, } \\
0.996^{* *}\end{array}$ & $\begin{array}{l}\text { Rhizobium, } \\
0.992^{* *}\end{array}$ & $\begin{array}{l}\text { Enterobacter, } \\
0.967^{* *}\end{array}$ & $\begin{array}{l}\text { Rhodococcus, } \\
0.896^{* *}\end{array}$ & $\begin{array}{l}\text { Carnobacterium, } \\
0.763\end{array}$ & $\begin{array}{l}\text { unclassified_A-A } \\
\text { ctinobacteria, } \\
0.923 * *\end{array}$ \\
\hline & $\begin{array}{l}\text { no_rank__ } \\
\text { Peptostreptococcaceae, } \\
0.787^{*}\end{array}$ & $\begin{array}{l}\text { no_rank_ } \\
\text { Peptostreptoc- } \\
\text { occaceae, } \\
0.821^{*}\end{array}$ & & $\begin{array}{l}\text { Flavobacterium, } \\
0.826^{*}\end{array}$ & $\begin{array}{l}\text { Chryseobacterium, } \\
0.966^{* *}\end{array}$ & $\begin{array}{l}\text { Streptococcus, } \\
0.788^{*}\end{array}$ & $\begin{array}{l}\text { Herbaspirillum, } \\
0.995 * *\end{array}$ & $\begin{array}{l}\text { Herbaspirillum, } \\
0.996^{* *}\end{array}$ & $\begin{array}{l}\text { Herbaspirillum, } \\
0.997^{* *}\end{array}$ & $\begin{array}{l}\text { Rhodococcus, } \\
0.935^{* *}\end{array}$ & $\begin{array}{l}\text { Streptococcus, } \\
0.814^{*}\end{array}$ & & \\
\hline & $\begin{array}{l}\text { Kluyvera, } \\
0.957 \text { ** }\end{array}$ & $\begin{array}{l}\text { Kluyvera, } \\
0.956 * *\end{array}$ & & $\begin{array}{l}\text { Carnobacterium, } \\
0.768^{*}\end{array}$ & $\begin{array}{l}\text { no_rank_Peptos- } \\
\text { treptococcaceae, } \\
0.860^{*}\end{array}$ & $\begin{array}{l}\text { Flavobacterium, } \\
0.902 * *\end{array}$ & $\begin{array}{l}\text { Chryseobacterium, } \\
0.990^{* *}\end{array}$ & $\begin{array}{l}\text { Chryseobacterium, } \\
0.990^{* *}\end{array}$ & $\begin{array}{l}\text { Chryseobacterium, } \\
0.989 * *\end{array}$ & $\begin{array}{l}\text { Flavobacterium, } \\
0.850^{*}\end{array}$ & $\begin{array}{l}\text { Flavobacterium, } \\
0.870^{*}\end{array}$ & & \\
\hline & Lactobacillus, 0.750 * & $\begin{array}{l}\text { Carnobacterium, } \\
0.903 * *\end{array}$ & & $\begin{array}{l}\text { no_rank_ } \\
\text { Spori-chthyaceae, } \\
0.866^{*}\end{array}$ & Kluyvera, 0.970 ** & $\begin{array}{l}\text { no_rank_- } \\
\text { Spori-chthyaceae, } \\
0.891 \text { ** }\end{array}$ & $\begin{array}{l}\text { no_rank_ } \\
\text { Bactero-idales, } \\
0.845^{*}\end{array}$ & $\begin{array}{l}\text { no_rank- } \\
\text { Bacteroid-ales, } \\
0.849^{*}\end{array}$ & $\begin{array}{l}\text { no_rank- } \\
\text { Bacteroid-ales, } \\
0.847^{*}\end{array}$ & $\begin{array}{l}\text { no__rank } \\
\text { Sporichth-yaceae, } \\
0.869^{*}\end{array}$ & $\begin{array}{l}\text { no_rank } \\
\text { Spo-richthyaceae, } \\
0.825 *\end{array}$ & & \\
\hline & $\begin{array}{l}\text { Carnobacterium, } \\
0.919^{* *}\end{array}$ & & & $\begin{array}{l}\text { Mesorhizobium, } \\
0.894 \text { ** }\end{array}$ & $\begin{array}{l}\text { Novosphingobium, } \\
0.852^{*}\end{array}$ & $\begin{array}{l}\text { Mesorhizobium, } \\
0.906 \text { ** }\end{array}$ & $\begin{array}{l}\text { no_rank_Peptost- } \\
\text { reptococcaceae, } \\
0.924^{* *}\end{array}$ & $\begin{array}{l}\text { no_rank_- } \\
\text { Peptostre- } \\
\text { ptococcaceae, } \\
0.906 \text { ** }\end{array}$ & $\begin{array}{l}\text { no_rank_ } \\
\text { Peptostre- } \\
\text { ptococcaceae, } \\
0.920^{* *}\end{array}$ & $\begin{array}{l}\text { Mesorhizobium, } \\
0.942 \text { ** }\end{array}$ & $\begin{array}{l}\text { Mesorhizobium, } \\
0.882 \text { * }\end{array}$ & & \\
\hline & & & & & $\begin{array}{l}\text { Lactobacillus, } \\
0.751^{*}\end{array}$ & $\begin{array}{l}\text { no_rank_ } \\
\text { Bacteria, } 0.773 \text { * }\end{array}$ & Kluyvera, 0.921 ** & $\begin{array}{l}\text { Kluyvera, } \\
0.896 * *\end{array}$ & $\begin{array}{l}\text { Kluyvera, } \\
0.912 \text { ** }\end{array}$ & & & & \\
\hline & & & & & $\begin{array}{l}\text { Carnobacterium, } \\
0.860^{*}\end{array}$ & & $\begin{array}{l}\text { Novosphingobium, } \\
0.971^{* *}\end{array}$ & $\begin{array}{l}\text { Novosphingobium, } \\
0.984^{* *}\end{array}$ & $\begin{array}{l}\text { Novosphingobium, } \\
0.976 * *\end{array}$ & & & & \\
\hline \multirow[t]{4}{*}{$\begin{array}{l}\text { negative } \\
\text { significiant } \\
\text { correlations }\end{array}$} & $\begin{array}{l}\text { Bacteroides, } \\
-0.803^{*}\end{array}$ & $\begin{array}{l}\text { Bacteroides, } \\
-0.7722^{*}\end{array}$ & $\begin{array}{l}\text { no_rank } \\
\text { Peptost- } \\
\text { reptococcaceae, } \\
-0.801^{*}\end{array}$ & $\begin{array}{l}\text { Prevotella, } \\
-0.753^{*}\end{array}$ & $\begin{array}{l}\text { Bacteroides, } \\
-0.763^{*}\end{array}$ & Kocuria, $-0.777^{*}$ & & & & & $\begin{array}{l}\text { Prevotella, } \\
-0.771^{*}\end{array}$ & $\begin{array}{l}\text { Prevotellla, } \\
-0.969 * * *\end{array}$ & $\begin{array}{l}\text { Erwinia, } \\
-0.740^{*}\end{array}$ \\
\hline & $\begin{array}{l}\text { Staphylococcus, } \\
-0.749^{*}\end{array}$ & $\begin{array}{l}\text { unclassified_- } \\
\text { Actinobacteria, } \\
-0.852^{*}\end{array}$ & & $\begin{array}{l}\text { Kocuria, } \\
-0.754^{*}\end{array}$ & $\begin{array}{l}\text { unclassified__- } \\
\text { Act-inobacteria, } \\
-0.80{ }^{*}\end{array}$ & $\begin{array}{l}\text { Staphylococcus, } \\
-0.779^{*}\end{array}$ & & & & & $\begin{array}{l}\text { Staphylococcus, } \\
-0.809^{*}\end{array}$ & $\begin{array}{l}\text { Kocuria, } \\
-0.957 * *\end{array}$ & $\begin{array}{l}\text { Kluyvera, } \\
-0.872 *\end{array}$ \\
\hline & $\begin{array}{l}\text { unclassified__ } \\
\text { Actino-bacteria, } \\
-0.856^{*}\end{array}$ & & & $\begin{array}{l}\text { Staphylococcus, } \\
-0.767 *\end{array}$ & & $\begin{array}{l}\text { unclassified_Act- } \\
\text { inobacteria, } \\
-0.793^{*}\end{array}$ & & & & & $\begin{array}{l}\text { unclassified_Act- } \\
\text { inobacteria, } \\
-0.799 *\end{array}$ & $\begin{array}{l}\text { Staphylococcus, } \\
-0.850^{*}\end{array}$ & $\begin{array}{l}\text { Streptococcus, } \\
-0.732 *\end{array}$ \\
\hline & & & & $\begin{array}{l}\text { unclassified_A- } \\
\text { ctinobacteria, } \\
-0.815^{*}\end{array}$ & & & & & & & $\begin{array}{l}\text { Kocuria, } \\
-0.792 *\end{array}$ & $\begin{array}{l}\text { unclassified_- } \\
\text { Actinobacteria, } \\
-0.942 \text { ** }\end{array}$ & $\begin{array}{l}\text { Lactobacillus, } \\
-0.731^{*}\end{array}$ \\
\hline
\end{tabular}


Table 4. Summary of the significant correlation coefficients between bacterial genus and the tea's chemical compounds.

\begin{tabular}{ccc}
\hline Bacterial Genus & Positive Significant Correlations & Negative Significant Correlation \\
\hline unclassified_Actinobacteria & TB & TPs, AA, EGC, C, EC, TF, TR \\
Klyyvera & TPs, AA, C, EGCG, GG, ECG & TB \\
no_ran__Peptostreptococcaceae & TPs, AA, C, EGCG, GG, ECG & CAF \\
Carnobacterium & TPs, AA, EGC, C, TR & TB \\
Erwinia & EGC, EC, GA, TF, TR & TB \\
Herbaspirillum, Rhizobium, Sphingomonas, Chryseobacterium & TPs, AA, C, EGCG, GG, ECG & \\
Enterobacter & EGC, EC, GA, TF, TR & \\
Kocuria & TB & EGC, EC, TF, TR \\
Staphylococcus & TB & TPs, EGC, EC, TF, TR \\
Bacteroides & TPs, AA, C \\
Flavobacterium, Mesorhizobium, no_rank_Sporichthyaceae, & EGC, EC, GA, TF & \\
Pantoea, Rhodococcus & C, EGCG, GG, ECG & \\
Novosphingobium & TB & EGC, TF, TR \\
Prevotella & EC, TF, TR & TB \\
Streptococcus & EGCG, GG, ECG & TB \\
Sphingobacterium & TPs, C & \\
Lactobacillus & EGCG, GG, ECG & C \\
Lactococcus & EC & \\
no_rank_Bacteria & CAF & \\
Pacrobacteriumibacillus, Stenotrophomonas & GA & \\
Pseudomonas & & \\
\hline
\end{tabular}

Table 5. Significant correlation coefficients between contents of the tea chemical compounds and the fungal genus.

\begin{tabular}{cllc}
\hline Compounds & \multicolumn{3}{c}{ Fungal Genus, Correlation Coefficients } \\
\hline C & Aspergillus, $-0.875^{*}$ & No_Rank_fungi, $0.867^{*}$ & - \\
EGCG & Aspergillus, $-0.959^{* *}$ & No_Rank_fungi, $0.984^{* *}$ & Penicillium, $0.863^{*}$ \\
GG & Aspergillus, $-0.974^{* *}$ & No_Rank_fungi, $0.990^{* *}$ & Penicillium, $0.875^{*}$ \\
ECG & Aspergillus, $-0.963 *$ & No_Rank_fungi, $0.988^{* *}$ & Penicillium, $0.872^{*}$ \\
\hline
\end{tabular}

Note: ${ }^{*}$ and ${ }^{* *}$ represent significance levels of 0.05 and 0.01 , respectively.

\subsection{Staphylococcus in SSF of Pu-erh Tea}

Staphylococcal food poisoning is a common food-borne disease worldwide following the ingestion of staphylococcal enterotoxins that are produced by enterotoxigenic strains, mainly Staphylococcus aureus [28]. S. aureus can grow in a wide range of temperatures, $\mathrm{pH}$ levels, and sodium chloride concentrations, and in many food products [29]. Bacteria belonging to the genus Staphylococcus accounted for $20.78 \%$ and $19.62 \%$ of the total reads at the last stages of SSF (day 28 and 35, respectively), suggesting that $S$. aureus occurs in the PFPT. To verify this possibility, a Baird-Parker plate assay to detect $S$. aureus and the isolation of bacteria in the day 28 and day 35 samples was performed. In total, 10 and one isolates in which the 16S rRNA genes (KP732727-KP732737) shared 100\% similarity to those of S. sciuri subsp. sciuri DSM 20345(T) and S. saccharolyticus ATCC 14953(T), respectively, were identified by an EzTaxon-e search [30]. However, S. aureus was not detected. The S. sciuri subsp. sciuri and S. saccharolyticus present in the fermentation of PFPT need further study to determine whether they are harmless symbionts or pathogens. However, their detection only at the last stage of SSF by pyrosequencing analysis suggested that the Staphylococcus came from the fermentation environment. Thus, we suggest that the safety of the environmental bacteria correlates with the safety of PFPT fermentation.

\section{Conclusions}

Spectrophotometry and HPLC revealed that the levels of TPs, FAA, EGC, EC, EGCG, GG, ECG, GA, TF, and TR decreased significantly $(p<0.05)$, while the TB content increased significantly $(p<0.05)$ after SSF. The pyrosequencing analysis and comparisons suggested that the bacteria in the initial stages 
of the SSF were from the raw material and environment, with Proteobacteria dominant in the raw material and at day 7 of SSF. Environmental bacteria were inoculated into the tea mass throughout the fermentation process and Firmicutes became the dominant bacteria at day 14 and 21. During the last stages of fermentation (day 28 and 35), Firmicutes and Actinobacteria were dominant. The dominant fungi were identified as genus Aspergillus in the SSF process. Correlations between microbial succession and the dynamics of the chemical compounds were conducted. This work provided information on the microbial succession and dynamics of chemical compounds, and the correlations between these two changes in the SSF of PFPT.

Acknowledgments: This work was supported by grants from The National Natural Science Foundation of China (Grant No. 31160174, 31560221 and 31260196), and Yunnan Agricultural University Outstanding scholar Project (Grant No. 2015JY05).

Author Contributions: Donglian Zang and Xiaoqin Su performed the experiments. Shuangmei Duan analyzed the data; Yan Ma and Ming Zhao designed the experimental procedure and wrote the paper. Dongying Zhang and Cai-you Lv provided partial fund. All authors read and approved the final manuscript.

Conflicts of Interest: The authors declare no conflict of interest.

\section{References}

1. Lv, H.; Zhang, Y.; Lin, Z.; Liang, Y. Processing and chemical constituents of Pu-erh tea: A review. Food Res. Int. 2013, 53, 608-618. [CrossRef]

2. Lee, L.K.; Foo, K.Y. Recent advances on the beneficial use and health implications of Pu-Erh tea. Food Res. Int. 2013, 53, 619-628. [CrossRef]

3. Stodt, U.W.; Blauth, N.; Niemann, S.; Stark, J.; Pawar, V.; Jayaraman, S.; Koek, J.; Engelhardt, U.H. Investigation of processes in black tea manufacture through model fermentation (oxidation) experiments. J. Agric. Food Chem. 2014, 62, 7854-7861. [CrossRef] [PubMed]

4. Wan, X.; Li, D.; Zhang, Z. Green Tea and Black Tea Manufacturing and Consumption. In Tea and Tea Products: Chemistry and Health-Promoting Properties; Ho, C.T., Lin, J.K., Shahidi, F., Eds.; CRC Press: Boca Raton, FL, USA, 2008; pp. 1-8.

5. Chen, H.; Lin-Shiau, S.; Lin, J. Pu-erh tea its manufacturing and health benefits. In Tea and Tea Products: Chemistry and Health-Promoting Properties; Ho, C.T., Lin, J.K., Shahidi, F., Eds.; CRC Press: Boca Raton, FL, USA, 2008; pp. 9-16.

6. Shao, W.; Powell, C.; Clifford, M.N. The analysis by HPLC of green, black and Pu'er teas produced in Yunnan. J. Sci. Food Agric. 1995, 69, 535-540. [CrossRef]

7. Zhao, M.; Xiao, W.; Ma, Y.; Sun, T.; Yuan, W.; Tang, N.; Zhang, D.; Wang, Y.; Li, Y.; Zhou, H.; et al. Structure and dynamics of the bacterial communities in fermentation of the traditional Chinese post-fermented pu-erh tea revealed by $16 \mathrm{~S}$ rRNA gene clone library. World J. Microb. Biotechnol. 2013, 29, 1877-1884. [CrossRef] [PubMed]

8. Abe, M.; Takaoka, N.; Idemoto, Y.; Takagi, C.; Imai, T.; Nakasaki, K. Characteristic fungi observed in the fermentation process for Puer tea. Int. J. Food Microbiol. 2008, 124, 199-203. [CrossRef] [PubMed]

9. Tian, J.; Zhu, Z.; Wu, B.; Wang, L.; Liu, X. Bacterial and Fungal Communities in Pu'er Tea Samples of Different Ages. J. Food Sci. 2013, 78, M1249-M1256. (In Chinese) [CrossRef] [PubMed]

10. Yang, X.P.; Luo, J.F.; Xin, L.; Liu, T.X.; Lin, W.T. Microbial Community Structure and Change during Solid Fermentation of Pu-erh Tea. Food Chem. 2013, 34, 142-147. (In Chinese)

11. Zhang, Y.; Zhao, S.; Liang, H.; Li, W.; Tengfei, Z.; Changwen, L. Changes of fungal community in Puer tea fermentation. China Brew. 2012, 1, 122-125. (In Chinese)

12. Lyu, C.; Chen, C.; Ge, F.; Liu, D.; Zhao, S.; Chen, D. A preliminary metagenomic study of puer tea during pile fermentation. J. Sci. Food Agric. 2013, 93, 3165-3174. [CrossRef] [PubMed]

13. Zhao, M.; Zhang, D.L.; Su, X.Q.; Duan, S.M.; Wan, J.Q.; Yuan, W.X.; Liu, B.Y.; Ma, Y.; Pan, Y.H. An Integrated Metagenomics/Metaproteomics Investigation of the Microbial Communities and Enzymes in Solid-state Fermentation of Pu-erh tea. Sci. Rep. 2015, 5, 10117. [CrossRef] [PubMed] 
14. Zhang, Y.; Skaar, I.; Sulyok, M.; Liu, X.; Rao, M.; Taylor, J.W. The Microbiome and Metabolites in Fermented Pu-erh Tea as Revealed by High-Throughput Sequencing and Quantitative Multiplex Metabolite Analysis. PLoS ONE 2016, 11, e157847. [CrossRef] [PubMed]

15. Gong, Z.; Watanabe, N.; Yagi, A.; Etoh, H.; Sakata, K.; Ina, K.; Liu, Q. Compositional change of Pu-erh tea during processing. Agric. Biol. Chem. 1993, 57, 1745-1746.

16. Lee, J.; Lee, B.; Chung, J.; Shin, H.; Lee, S.; Lee, C.; Hong, Y. 1H NMR-based metabolomic characterization during green tea (Camellia sinensis) fermentation. Food Res. Int. 2011, 44, 597-604. [CrossRef]

17. Qin, J.H.; Li, N.; Tu, P.F.; Ma, Z.Z.; Zhang, L. Change in tea polyphenol and purine alkaloid composition during solid-state fungal fermentation of postfermented tea. J. Agric. Food Chem. 2012, 60, 1213-1217. [CrossRef] [PubMed]

18. Gong, S.; Chengyin, L.; Xu, L.; Yuxiang, Z.; Hong, S.; Yalin, G.; Jihong, W.; Lei, Z.; Zilei, G. Methodology of Sensory Evaluation of Tea GB/T 23776-2009; China Agriculture Press: Beijing, China, 2009.

19. Liang, Y.; Zhang, L.; Lu, J. A study on chemical estimation of Pu-erh tea quality. J. Sci. Food Agric. 2005, 85, 381-390. [CrossRef]

20. Wang, Q.; Peng, C.; Gong, J. Effects of enzymatic action on the formation of theabrownin during solid state fermentation of Pu-erh tea. J. Sci. Food Agric. 2011, 91, 2412-2418. [CrossRef] [PubMed]

21. Schloss, P.D.; Gevers, D.; Westcott, S.L. Reducing the effects of PCR amplification and sequencing artifacts on 16S rRNA-based studies. PLoS ONE 2011, 6, e27310. [CrossRef] [PubMed]

22. Schloss, P.D.; Westcott, S.L.; Ryabin, T.; Hall, J.R.; Hartmann, M.; Hollister, E.B.; Lesniewski, R.A.; Oakley, B.B.; Parks, D.H.; Robinson, C.J.; et al. Introducing mothur: Open-source, platform-independent, community-supported software for describing and comparing microbial communities. Appl. Environ. Microb. 2009, 75, 7537-7541. [CrossRef] [PubMed]

23. Edgar, R.C.; Haas, B.J.; Clemente, J.C.; Quince, C.; Knight, R. UCHIME improves sensitivity and speed of chimera detection. Bioinformatics 2011, 27, 2194-2200. [CrossRef] [PubMed]

24. Huse, S.M.; Dethlefsen, L.; Huber, J.A.; Mark, W.D.; Relman, D.A.; Sogin, M.L. Exploring microbial diversity and taxonomy using SSU rRNAhypervariable tag sequencing. PLoS Genet. 2008, 4, e1000255. [CrossRef]

25. Quast, C.; Pruesse, E.; Yilmaz, P.; Gerken, J.; Schweer, T.; Yarza, P.; Peplies, J.; Glockner, F.O. The SILVA ribosomal RNA gene database project: Improved data processing and web-based tools. Nucleic. Acids Res. 2013, 41, D590-D596. [CrossRef] [PubMed]

26. Wang, Q.; Garrity, G.M.; Tiedje, J.M.; Cole, J.R. Naive Bayesian classifier for rapid assignment of rRNA sequences into the new bacterial taxonomy. Appl. Environ. Microbiol. 2007, 73, 5261-5267. [CrossRef] [PubMed]

27. Kemp, P.F.; Aller, J.Y. Bacterial diversity in aquatic and other environments: What $16 \mathrm{~S}$ rDNA libraries can tell us. FEMS Microbiol. Ecol. 2004, 47, 161-177. [CrossRef]

28. Hennekinne, J.A.; De Buyser, M.L.; Dragacci, S. Staphylococcus aureus and its food poisoning toxins: Characterization and outbreak investigation. FEMS Microbiol. Rev. 2012, 36, 815-836. [CrossRef] [PubMed]

29. Kadariya, J.; Smith, T.C.; Thapaliya, D. Staphylococcus aureus and staphylococcal food-borne disease: An ongoing challenge in public health. BioMed Res. Int. 2014, 2014, 827965. [CrossRef] [PubMed]

30. Kim, O.S.; Cho, Y.J.; Lee, K.; Yoon, S.H.; Kim, M.; Na, H.; Park, S.C.; Jeon, Y.S.; Lee, J.H.; Yi, H.; et al. Introducing EzTaxon-e: A prokaryotic 16S rRNA gene sequence database with phylotypes that represent uncultured species. Int. J. Syst. Evol. Microbiol. 2012, 62, 716-721. [CrossRef] [PubMed]

(C) 2017 by the authors; licensee MDPI, Basel, Switzerland. This article is an open access article distributed under the terms and conditions of the Creative Commons Attribution (CC BY) license (http:/ / creativecommons.org/licenses/by/4.0/). 